\title{
Small-scale Commodity Frontiers: The Bioeconomy Value Chain of Castor Oil in
}

\section{Madagascar}

The European Commission defines the bioeconomy as a 'transition economy which seeks to increase efficiency, optimize use and decrease environmental impact through the reduction of waste and greenhouse gas emissions.' However, attempts to substitute or control nature through efficient bio-based technology have not lived up to expectations and much of the industry still relies on globally sourced biomass to drive the bioeconomy. This article examines the social and political economic relations surrounding small-scale production of the feedstock castor oil plant (castor, Ricinus communis) in the deep-south of Madagascar. Theorizing the bioeconomy through the lens of a 'small-scale commodity frontier', it builds from recent injunctions by Jason Moore to show how the appropriation of cheap nature (including paid and unpaid labour) is both historically and geographically coproduced. The castor value chain is held up as a way to transform regional economies and a 'silver bullet' to alleviate poverty and food security in some of the most economically marginal areas of Madagascar. We adopt a reginal and feminist political ecology approach to illustrate what is behind this discursive cloak of 'development imaginaries', making visible the social relations surrounding castor production and demonstrating the historical marginalization involved in producing the frontier.

The bioeconomy is one of the oldest economic sectors known to humanity, and the life sciences and biotechnology are transforming it into one of the newest

European Commission 2005, 2; quoted in Birch and Tyfield 2013 


\section{INTRODUCTION}

'The bioeconomy starts here!' This is the title of an animated video promoting the European Commission bioeconomy initiative touting 'inclusive sustainable development' through the rise of an economy founded on manufacturing in biotechnology laboratories in Europe. The European Commission defines the bioeconomy, as a 'transition economy which seeks to increase efficiency, optimize use and decrease environmental impact through the reduction of waste and greenhouse gas emissions. ${ }^{2}$ Key to the bioeconomy's success, argue its proponents, is the adoption of 'knowledge-based' biotechnology (i.e. technoscience). This has the capacity to increase the accessibility of sustainable biomass on an industrial scale, including flexi-crops (crops with dual purposes, such as fuel and food) and, through conversion using innovations such as GM microbial enzymes and advanced bio-refineries, low-cost non-edible feedstock (Borras et al. 2016). ${ }^{3}$ In theory, biotech's coupling of 'genetic and bio-molecular science' in the 'intensification of natural productivity for commercial exploitation' promises to deliver a portfolio of bio-innovations, including alternative forms of energy (e.g. biofuels), intermediate inputs (e.g. biochemicals), and natural products (e.g. pharmaceuticals, bioplastics) (Birch et al. 2010, 2899; see also Birch et al. 2010; Levidow 2011).

Yet up to this point, biotechnology's attempts to control or 'engineer' nature within laboratories in Europe have not lived up to expectations and much of the industry still relies on globally sourced and resource-intensive biomass to fuel the bioeconomy (McMichael

\footnotetext{
${ }^{1}$ See http://ec.europa.eu/programmes/horizon2020/en/news/bioeconomy-video-spreads-word [accessed on 2 November 2015].

${ }^{2}$ See http://ec.europa.eu/research/bioeconomy/policy/bioeconomy_en.htm [accessed on 1 November 2015].

${ }^{3}$ There are a number of crops which can be identified as flexi-crops; the main ones are soybean, sugarcane and palm oil.
} 
2012). ${ }^{4}$ In the past few years, increasing demand for massive amounts of low-cost feedstock has caused socio-economic conflict over land and environmental degradation throughout the global south (Carmody 2011; McMichael 2009; 2012). ${ }^{5}$ Many of these effects, from the dispossession of farmers due to large-scale land acquisitions, or 'land-grabbing', to rainforest clearing and increased competition with food crops, have been widely documented (Borras et al. 2010, 2012; Vermeulen and Cotula 2010; White and Dasgupta 2010). In response, there have been attempts to reform production by implementing new sustainable certification schemes (Bailis and Baka 2011; Ponte and Birch 2014), fairer labour practices (Garvey et al. 2015), and land tenure guidelines for foreign investment (Fairbairn 2015; World Bank 2010). Many of these, however, have either not been fully adopted or made little impact within rural sites of production.

While scholarly work on the bioeconomy is beginning to appear, the majority has been largely theoretical, focusing mainly on the role of technoscience and structural flows of capital and financialization of the biotech industry (Birch and Tyfield 2013; Birch et al. 2010; Levidow 2011). Although there is certainly value in framing the bioeconomy as a concept of high-modernism and within a very particular etymological relation to capitalism, we also see the importance of understanding it as 'lived practice', where material implications of biomass sourcing on small-scale outgrowers (also known as contract farmers) are observed through a historical lens of socio-economic and political marginalization (Borras and Franco 2011; Oya 2012). ${ }^{6}$

\footnotetext{
${ }^{4}$ Biomass is the generic term for resource inputs in the form of oil-seed and soybean feedstock, bluegreen algae, and ligno-cellulosic and crop residues which through chemical processes create a host of products and services.

${ }_{5}^{5}$ This demand was driven by two alternative energy policies, the EU Alternative Energy Mandate and the US EP Act 2005 Renewable Fuel Standard (RFS), as well as new bioeconomy initiatives promoted by the OCSD and EU.

${ }^{6}$ Small-scale production is defined as production from $1-10$ ha. While the focus in this paper is castor oil, there is also parallel production of Jatropha sp. integrated in this chain.
} 
Although significant debates exist on their significance as compared to larger commercial production systems using plantations, outgrowers, to variable degrees depending on crop and commodity-specificity, have been a mainstay of agricultural production systems in subSaharan Africa (Cotula et al. 2009; Watts 1994). ${ }^{7}$ Nevertheless, the adoption of outgrowers for bioeconomy projects seem to be on the rise and with mixed outcomes (Alonso-Fradejas 2012; Gerber and Veuthey 2010; Guereña and Zepeda 2013). This is particularly the case in Madagascar, where firms and their development partners see outgrowers as an alternative to the high-profile cases of large-scale land acquisitions that have plagued the country since the Daewoo land deal and subsequent political crisis of 2008-9 (Burnod et al. 2015). While outgrowers more generally do not experience dispossession in the same way as observed with large-scale acquisitions and plantation-style production systems, as we see below, their experiences of marginalization and exploitation exhibit similar, albeit subtler, forms of violence to that of forced evictions (Li 2011; Borras and Franco 2011, see also Kelly 2011) ${ }^{8}$

The aim of this article is to examine the social and political economic relations surrounding the value chain of the castor oil plant (Ricinus communis) run by a Franco-Malagasy bio-oil firm in the deep-south of Madagascar. Castor has been produced in Madagascar for use in the pharmaceutical and cosmetics industries since colonial times. More recently, the plant, alongside other key crops (i.e. jatropha, soybean, switch grass and now flexi-crops), have at varying times and with different degrees of success, been held up by development agencies as a so-called 'silver-bullet' commodity which, they argue, through a 'value-chain approach', can alleviate poverty and address food security in some of the most economically marginal

\footnotetext{
${ }^{7}$ See Oya $(2012,14)$ for an extensive review of the purported role, significance and methodological deficiencies in systematic calculations of contract farming in sub-Saharan Africa. There is also methodological challenge of case studies, including florists in Kenya and horticulturalists in Senegal, which on the surface seem to be small-scale but feed into larger commercial production systems.

${ }^{8}$ What Kelly (2011) calls 'veiled' accumulation or the deliberate attempt to mask the violent acts of dispossession over long periods of time.
} 
regions of Madagascar. ${ }^{9}$ Development agencies have tied their hopes on such commodity crops to fuel particular 'sustainable development imaginaries' - 'the self-conscious making of a spectacle' (Tsing 2000,118) - used to entice foreign investment and direct favourable policies which promote the use of global markets to address some of the most difficult problems facing rural inhabitants. Yet, as Borras et al. (2016) and others (Hunsberger and Alonso-Fradejas 2016; Neimark 2016) note, the performance of such discursive and fetishized 'bioeconomy imaginaries' has consequences way beyond their intended purpose, exposing many at the rural level to come head-on with the risks of global capital. Following Marx's oft-cited quote that the ' $\ldots$ fetishism of commodities has its origin .... in the peculiar social character of the labour that produces them' (Marx and Engels 1970, 77), we critically examine what is behind this fetishism of the bioeconomy to render visible the hidden material relations (labour mobilization, gender relations) and social costs surrounding castor production. Elucidating labour relations in biomass production helps identify the bioeconomy's 'origins' across space and time - not within the 'bundles of innovations' in European biotech laboratories as alluded to in the European Commission's promotional video, but on the backs of labourers in the deep-south of Madagascar. ${ }^{10}$

Although today Madagascar represents just a fraction of total global production, we demonstrate the great lengths (and distances) that firms and large development agencies, such as the United Nations Development Programme (UNDP) and the European Community in partnership with the German Development Agency (GIZ), are willing to go to source biomass and bring Malagasy labour within the circulation of capital (see below for further description of agencies). Results show that for benefits in the form of merger cash payments for castor

\footnotetext{
${ }^{9}$ See van Eeckhout 2015. This is a historical pattern of silver-bullet development crops, from the agroforesty wonder tree Leucaena sp., to neem and the current slew of flex or biofuel crops (Borras et al. 2016).

${ }^{10}$ This is analogous to Marley's (2016) comment about the emergence of capitalism emanating not from the textile smokestacks of the nineteenth century industrial revolution, but from the long sixteenth and seventeenth century slave labour of the Americas and Caribbean.
} 
seeds, outgrowers take on the extra work of transporting the seeds long distances and the additional risks of production (crop failure due to drought or disease), all in the name of poverty reduction and sustainable development. We provide a critical window into how and why a small-scale bioeconomy frontier develops and paradoxically how attempts to bring a precarious labour force into the circulation of capital relations are placing the most vulnerable face-to-face with the variants of global capitalism (Polanyi ([1944] 2001).

This paper makes an original contribution to Jason Moore's (2015) theoretical framework of 'commodity frontiers' by applying it to the bioeconomy. Building on recent injunctions by Campling (2012) and others (Marley 2016; Saguin 2015), we use a 'small-scale bioeconomy frontier' to show how the bioeconomy industry - itself in a contemporary crisis of overaccumulation within a carbon-constrained economy - is unable to source biomass in bulk and/or deliver the knowledge-based innovations needed to replace it altogether. Under such conditions of potential diminishing returns, the industry expands spatially to new areas across the globe where it can source low-cost feedstock (both in new forms of biomass, such as flexi-crops, and older historical colonial crops, such as castor) in order to continue accumulation. ${ }^{11}$

Following Saguin, we show that agrarian change in the bioeconomy is still essentially an ‘ecological agrarian question' which Akram-Lodhi and Kay $(2010,269)$ argue ‘...must critically investigate the character of ecological relationships ... and in so doing address contradictions of class and ecology if it is going to explain social change in contemporary rural settings' $(2010,269)$. The bioeconomy is fraught with socio-technical and political economic contradictions and crises whereas the 'rural production process' must continually

\footnotetext{
${ }^{11}$ Moore's $(2015,9)$ post-Cartesian 'world ecology' approach extends this dialectical relationship between society and nature, attempting a unification of humanity and nature through a 'web of life' perspective which sees human and extra-human nature through a lens of capital accumulation. However, Campling (2012), Saguin (2016) and to some degree Marley 2016 tend at times to hold on to the classic nature-society dialectics).
} 
contend with the limits of 'agroecological resources, whether monetarily costed or noncosted', and which 'contribute to or constrain the process of accumulation' (Akram-Lodhi and Kay 2010, 269). As Saguin notes, '[t]he production of commodity frontiers is a process enacted through ecological revolutions wherein capital appropriates ecological surpluses cheap labour, food, energy and inputs - at a low cost by mobilizing labour power and extrahuman nature' $(2015,2)$. We highlight and differentiate the spatial-temporal cycle of opening up or widening and intensifying or deepening engagement with nature of the small-scale bioeconomy industry, which facilitates the appropriation of previously non-commodified resources (due to exhaustion of stocks and socio-technical constraints) and a greater exploitation of paid labour and appropriation of unpaid labour (household reproduction, transporting and sourcing of semi-wild crops which nature provides 'free of charge'). ${ }^{12} \underline{\text { This }}$

This paper proceeds in five sections. First, we lay out an overview of Jason Moore's theory of commodity frontiers and its relationship to other studies examining similar work around the agrarian question. We address how the concept relates to the material relations surrounding the bioeconomy and agrarian change. In the second section, we provide a historicalgeographical background to castor production in Madagascar, from the colonial period to the contemporary quest to seek out new production. The paper departs from recent scholarship's sectoral and world systems approach to understanding commodity frontiers (Campling 2012; Moore 2015). Rather, our empirical analysis draws on the unique perspectives of harvesters, traders, mid-level managers and firm operators of castor production. We adopt both a regional and to some degree a feminist political ecology approach to critically understand the

\footnotetext{
${ }^{12}$ As Moore (2015) notes, 'the accumulation of capital unfolds at the nexus of paid work (performed by some humans) and unpaid work (performed by most humans, and all extra-human natures).' The former is exploitative wage labour and the latter includes hidden labour which is performed in the service of capitalism (household labour, animals, labour of ecosystem services, etc.). See https://jasonwmoore.wordpress.com/2014/04/25/beyond-the-exploitation-of-nature-a-worldecological-alternative/ [accessed on 18 November 2016].
} 
material relations of the castor value chain embedded in its distinctive geo-historical and political economic landscape of marginalization (Blaikie 1985; Broch-Due and Schroeder 2000; McKinnon and Hiner 2016; Neumann 2005; Rocheleau et al. 1997; Schroeder 1999). We conclude by discussing the implications of viewing the bioeconomy through the lens of a commodity frontier and opportunities and shortcomings of using this lens in the application of a case study of small-scale growers.

\section{Methodological Considerations}

This work builds from data collected in June and July in 2012 and 2014, respectively; this ethnographic fieldwork consists of over 120 semi-structured interviews and socio-economic surveys with harvesters of castor and farmers of other crops, as well as key interviews with heads of village associations, representatives of the castor processing firm and development NGOs in the deep-southern regions of Anosy and Androy in Madagascar. ${ }^{13}$

The interviews focused on a regional Franco-Malagasy agricultural export firm, which has been in operation since 2009 and is one of a few companies which have attempted to revive castor production from its colonial past. We follow the production system chain to highlight the perspectives of people who are involved in growing and wild collection of castor for the bio-oil firm, as well as exporting it for European buyers who purchase the pressed oil in bulk for the manufacture of bioplastics, biofuels and the cosmetics industry. ${ }^{14}$ Subjects were chosen because of their close relationship to the firm as employees, family members of contract workers, or non-growers living in villages where the firm operates.

\footnotetext{
${ }^{13}$ These are two of the 22 regions of Madagascar which since 2009 have become 'first-level' administrative divisions and sit in the District of Amboasary-Atsimo (second-level). These two regions have a population of roughly 1.5 million inhabiting an area of $45,200 \mathrm{~km}^{2}$. The majority of these are subsistence farmers living on customary tenure plots of roughly 1.3 ha (FAO 2016).

${ }^{14}$ Interview with regional manager [7 July 2014].
} 
The firm's financial and logistical support is provided by a larger private-public initiative, the Food Security Improvement and Increased Agricultural Income Programme (ASARA), funded by the European Commission's Development Fund (GIZ 2014) and UNDP, and in partnership with GIZ, the German NGO ${ }^{15}$ ASARA's main objectives are to address food insecurity through the incorporation of vulnerable households into sustainable development based on export-intensive agricultural commodities. The castor firm is private but has been financially supported and provided with technical equipment by ASARA; logistical support has also been provided by GIZ. As with many agricultural projects in southern Madagascar, there is little financial or technical support provided by Malagasy state agencies. Interviews included members of many of these civil society groups involved in this project.

\section{THEORETICAL POSITIONING}

Recently, the concept of 'commodity frontiers' has emerged as a novel way to trace socioecological shifts and nested contradictions that are inherent in capitalism and its relationship to nature (Foster and Clark 2009; Marley 2016; Moore 2000, 2010, 2015; O’Connor 1998). Specifically, the theory of commodity frontiers looks at socio-ecological processes using a 'world ecology' approach, illustrating both exploitation of paid labour power and appropriation of unpaid work (performed by most humans, and all extra-human natures nature's free gifts) (Araghi 2009; Moore 2010, 2015). While these various theories help in the understanding of how 'value chains' form, for us, the concept of a small-scale commodity frontier links up the historical and regional specificity - the vertical and horizontal relations amongst firms involved in production and consumption of castor oil used for the bioeconomy (Campling 2012, 225; see also Moore 2015).

\footnotetext{
${ }^{15} \mathrm{GIZ}$ is the successor NGO to what was previously called GTZ - a development arm of the German Federal Ministry for Economic Cooperation and Development (BMZ) operating in public-private partnerships in rural and urban development in Madagascar since 1982.
} 
So what does it mean to call the bioeconomy a 'commodity frontier?' Commenting on the use of 'frontier', the environmental anthropologist David Hughes notes: 'The term frontier means two things, both of them strikingly political ... The frontier is a zone, a hinterland, lying outside the spatial core of a society but within grasp ... yet they also bound and demarcate national, sovereign territories ... the same frontier can both permit and circumscribe conquest, even at the same time' $(2011,3)$. This study of the bioeconomy unveils the uneven landscape of labour relations around the small-scale sourcing of castor oil within some of the most historically marginalized rural producers in Madagascar. Moving beyond a geohistorical and sector-dominated analysis found in recent commodity frontier work, it espouses a regional and feminist political ecology approach which, first, highlights the distinction of regional socio-ecological politics (Blaikie 1985; Neumann 2005; Walker 2003) and, second, highlights regional discursive formations (Peet and Watts 2002, 16) that 'originate in, and display the effects of, certain physical, political-economic, and institutional settings. Furthermore, by integrating feminist political ecology we make a key point in highlighting gender as a crucial variable in constituting access and control of resources and unevenness of value-chain development (Harcourt and Nelson 2015; Rocheleau et al. 1997; Schroeder 1999). We argue that although there are strands of both feminist and regional political ecology embedded in the commodity frontier concept, their adoption by scholars as an analytical lens is often less observed. Results show how the ecological particularities of castor - that it grows and can be accessed by women in semi-wild areas - engenders a particular division of labour. This paradoxically both empowers women collectors while also placing burdens on them to transport it very long distances for little or no pay.

Rather than simply accepting bioeconomy 'frontiers' as being part of a concept of abstract space waiting to be enclosed and commodified, we follow Peet and Watts $(2002,16)$, who examine the 'power-saturated interactions and interchanges' with marginalized groups 
immersed in discursive formations and articulations about value-chain development. It is through the lens of a small-scale commodity frontier that we are able see the lived bioeconomy of castor, which is rooted within a complex history of marginalized populations, discursively and materially produced in a certain way for the reproduction of capital (Borras et al. 2016; Campling 2012; Ribot 1998).

This bundle of abstract social and material relations links up to the real, anticipated or speculative and imagined narratives put forth by Borras et al. $(2012,105)$ which helps explain the complexity of layered promotion of commodity flex-crops and the extensive social implications of discursive narratives even in the absence of the commodity ever materializing. Much like the flex-crop narrative, the regional development narrative pushed forth under castor oil value chains is an example of the bioeconomy responding to the social and environmental crisis of over-accumulation.

While the commodity frontier framework draws heavily from world-systems, its approach to long histories is distinct in how it views resources and ecological change (Moore 2010). Rather than something that acts negatively upon nature, the concept highlights the 'appropriation of nature for the production of commodities for exchange' (Campling 2012, 225 , emphasis in original) where 'relatively durable patterns of governance (formal and informal), technological innovations, class structures, and organizational forms that have sustained and propelled successive phases' extend accumulation (Moore 2015, 158; see also Araghi 2009). In this sense, the small-scale bioeconomy frontier 'is not merely just a system of unpaid costs (known as "externalities"), it is a system of unpaid work ("invisibilities")' (Moore 2015, 64).

Thus, for us, the small-scale bioeconomy frontier not only extends and deepens human and extra-human nature into areas such as southern Madagascar which are relatively unknown to capital, but also opens up new possibilities for entering zones of 'appropriation of high 
ecological surplus' (Campling 2012, 256). Yet, as we argue, such 'possibilities' of frontier formation do not appear randomly nor are they abstractions constructed within development imaginaries (food security, income generation), but are produced over long historical periods of marginalization and uneven development (see Broch-Due and Schroeder 2000).

\section{The Bioeconomy and the Ecological Agrarian Question}

At one level, the ecological agrarian question remains as relevant in the bioeconomy as it once did to nineteenth century thinkers, who first described the phenomenon of the 'persistence' and 'self-exploitation' of the 'family' or small-scale producer (cf. Akram-Lodhi and Kay 2010). For Bernstein $(2010,94)$ and others (Kautsky 1988; Mann and Dickinson 1978) the persistence, or staying-power, of the small-scale farmer is 'tolerated' and even 'encouraged' by capital mainly because farmers will subsidize their costs by growing their own food and providing labour power (wages). In other words, small-scale producers can be paid less because the wage does not have to cover household-based 'social reproduction', which is taken care of by the farmers themselves (Bernstein 2010, 94). The recent 'greening' discourse relating to the bioeconomy has opened new pathways for rethinking the agrarian question once again as new spaces of cheap nature in the global south are appropriated for green ends or 'green grabbing' (Fairhead et al. 2012) and as noted above, framed under 'inclusive' economic and social development.

Critical scholars have shown how market-driven development capital allows for both widening and deepening capitalist penetration into the rural countryside (de Janvry 1981). However, less scholarly attention has been paid to seeing the bioeconomy as a commodity frontier and in particular the material consequences as the search for new biomass enters a new temporal phase of global expansion. We see this as a significant departure from previous work and how values are captured in forms of un-commodified nature (Neimark et al. 2016). Unlike most studies, which take an approach which considers commodity production to be 
place-specific, biomass production is highly transitory, mobile and flexible. The 'small-scale' bioeconomy commodity frontier tends to develop in places where a commodity can be produced under minimum capitalization, ${ }^{16}$ but where private sector firms, NGOs and their development funders see large amounts of cheap land, labour and resources ripe for commodification (Moore 2015; see also Campling 2012; Saguin 2015). This case of a smallscale bioeconomy commodity frontier is one where expansion dynamics are largely defined by cheap capitalization - as capital is not available to small-scale producers of speciality crops where biomass, once a colonial crop, is now being re-appropriated for a range of new uses - from fuels to industrial products. One way this is possible is for capital to make the risks of commodity production low through a host of 'invisible' intrinsic costs (i.e. cheap food, household labour and transport of wild castor) and risks (crop failure) that rural producers will take on for little benefit.

This becomes operationalized through an adoption of development discourse surrounding 'value chains', which funders of small-scale bioeconomy projects have instituted in order to secure global biomass 'yield gaps' and keep as much of the upstream transformation and processing activities 'in country', thereby increasing market share in the commodity (Richer 2015). ${ }^{17}$ Counter to applied empirical uses of the terms (cf. Gibbon and Ponte 2005), 'value chain', and others such as 'upgrading', are in themselves discursive constructions providing cover for firms to continue to widen spatial access. A value chain, as McMichael $(2013,627)$ aptly remarks, ‘...is represented as a benign facilitator of agricultural productivity and rural

\footnotetext{
${ }^{16}$ This is in contrast to high capitalization costs such as increased need for inputs, mechanization and transport of raw materials. It is also dissimilar to other parts of the bioeconomy, such as palm oil, corn, soybean, sugarcane and tree-based production mills, which require new, massive biorefineries built close to plantation areas; certification schemes, such as the roundtable for sustainable biofuels and Clean Development Mechanism (CDM) also require capitalization in the form of scientific and technical expertise (Alonso-Fradejas et al. 2016).

${ }^{17}$ For more specific work on value chains and especially analytical frameworks for buyer-driven chains see Gibbon and Ponte (2005). We recognize that 'funders' of projects are a diverse array of actors including civil society, multinationals, medium and small companies, bi-/multi-lateral and state aid agencies which to differing degrees pick up on bioeconomy discourse in different ways (see Hunsberger and Alonso-Fradejas 2016).
} 
income, its power relations are explicit in the term itself' articulating the capacity 'to appropriate the unpaid work of nature (including humans), coupled with the exploitation of cheap labour' (Marley 2016, 4).

Seeing the bioeconomy as a commodity frontier also provides a window into the intersections of socio-technological engagement with nature and how ecological constraints open up opportunities for capital to deepen commodification (Campling 2012; Castree 2004). The role of technology in mediating productive practices has been observed by scholars looking at the effects of new and emerging science and capitalism in agriculture (Goodman and Redclift, 1991). Goodman and Redclift (1991) and Goodman et al. (1987) provide the key concepts of 'appropriationism' and 'substitutionism' to express ways that agricultural capitalists overcome the natural barriers in agriculture or at least reduce the effects of these temporal disruptions in the realization of capitalist profits. They use appropriationism to express innovations made to reduce the effects of natural cycles, thereby facilitating the accumulation of capital.

Continuing this line of thinking, the bioeconomy is also attempting substitutionism of its own terms. While the original conceptualization of substitutionism refers to the complete replacement of 'natural' products altogether, the bioeconomy can be seen as a way for the biotech industry to reverse the process and replace the inorganic with the organic, bringing with it a host of hitherto non-commodified resources into the circulation of capital (Goodman et al., 1987; see also Goodman and Redclift 1991). An example of substitutionism in this way includes the adoption of natural fibres to replace synthetic fibres, or in the case of bioprospecting the use of natural bioactive chemical compounds which can replace synthesized drugs. Yet as we demonstrate, the inability of capital to completely manipulate the factors and relations of the bioeconomy through new innovations has become a key constraint in successfully being able to disengage from nature, and therefore the industry 
Please note: This is a pre-edited copy.

must still contend with accumulating cheap biomass from large-scale plantations and smallscale outgrowing systems.

\section{REGIONAL POLITICAL ECOLOGY: COLONIAL TO PRESENT-DAY CASTOR PRODUCTION}

While development agencies' efforts are by no means exclusive to southern Madagascar, the direct targeting of the population for poverty alleviation and food security is for good reason. Madagascar's rank in the UN Human Development Index (HDI) is 154 (out of 188) with over 87.7 per cent of its population of 23.6 million living below the income poverty line of $\$ 1.25$ per day. ${ }^{18}$ Androy and Anosy consistently have some of the highest rates of poverty and populations are ranked as the most 'at risk' of chronic malnutrition and food security. ${ }^{19}$ The region is home to a mosaic of subsistence farmers and production systems, including pastoral nomads, irrigated rice, maize and cassava, and fishing. These mainly subsistence farmers manage their livelihoods, which includes both simple or 'petty' commodity production of some basic surplus under cycles of consecutive drought, cyclones and locust invasions which have been particularly severe in the past few years (FAO 2016). ${ }^{20}$ Women farmers in the region are particularly vulnerable as the majority of farmland is locally recognized under customary tenure, which follows male lineage. ${ }^{21}$ For example, if a woman separates from her husband or the husband dies, and she has no male children to whom some land could be directed, she may have to return to her family to access land to grow food. The alternative is to risk severe sanctions if she tries to use his land. Women take on the post-harvest activities

\footnotetext{
${ }^{18}$ HDI 2014.

${ }^{19}$ According to the Oxford Poverty and Human Development Initiative (OPHI) Country Briefing (2013) the two regions Androy and Anosy were listed as having 66 and 56 per cent of the population in severe poverty, respectively.

${ }^{20}$ For a further discussion of simple commodity production as an analytic category see Friedmann $1980 ; 1990$.

${ }^{21}$ Rural women constitute 36 percent of the ag population and the female economic activity rate in the ag sector is about 53 percent (FAOSTAT 2016).
} 
associated with subsistence 'garden' crops and are dependent on their husband's access to viable land for production. ${ }^{22}$

Yet, the poverty and livelihood instability plaguing southern Madagascar is not necessarily new, as Anosy and Androy have for the better part of the twentieth century been observed by scholars as a 'development backwater.' The discursive construction of the 'underdeveloped south' was not helped by years of policies - first from the ruling highland Merina Monarchy, then the French, and later successive central governments - of political and economic marginalization of the southern Tandroy and Tanosy (and some Mahafaly) groups (Heurtebize 1986). Over the years this helped instil a political isolationism in the southern region and, throughout most of the nineteenth and twentieth centuries, groups in the south had tried and sometimes succeeded in maintaining their independence from the Merina Monarchy during the process of unification. This independent streak held until the French took over in the early 1900s, and even then, regions of Androy where kept in an emergency state until 1917 due to sporadic resistance. This struggle against the French caused the eventual build-up of colonial forces vying for a more permanent presence in the region. Yet, during the colonial period, elements of defiance in the south to outside influences were compounded by provocative tactics of 'divide and rule' by the French to maintain the divide between many of the coastal populations and the highland Merina (Ramandimbilahatra, 2010). ${ }^{23}$ This political resistance held up until well into the mid-twentieth century, which in 1971 ignited in a popular uprising against the independent state (Heurtebize 1986).

The eventual desire by the French to 'develop the deep-south' was based on a dual policy to control these unruly local populations and begin to create a reliable revenue stream from the

\footnotetext{
${ }^{22}$ In these extreme cases many women find themselves as landless farmers navigating a very difficult livelihood of working someone else's land or harvesting castor off refused land.

${ }^{23}$ In the twenty-first century, the region still remains isolated and deprived of access to education and training by comparison with many other parts of the country (Droy et al. 2010).
} 
region. In particular, the French were seeking to 'ground' the mobile peasant-herder communities found in the southern ethnic groups into discrete, administrable - and therefore taxable - villages (Kaufmann and Tsirahamba 2006). This strategy led to considerable social discord which reached a head during World War I as taxation demands to support France's war efforts were rebuked by the majority of Malagasy, particularly in the south. For instance, in the Androy region, a local Malagasy administrator gathered a large force together and refused to pay taxes or provide services to the French, proposing instead to kill colonizers and run them out of southern Madagascar (see Gontard 1969). Nevertheless, beyond these insurrections, Madagascar's colonial magistrates during the inter-war years were successful in implementing agricultural schemes for cash crops and forestry using French colons (settlers) and coerced labour (Jarosz 1996; Sodikoff 2012). It was at this time that colonial plantations of castor, alongside sisal, periwinkle and prickly-pear cactus (raketa), were meant to generate revenue from the southern regions of Anosy and Androy (Middleton 1999). ${ }^{24}$ Not coincidentally, these same regions are also targeted for today's castor projects.

\section{Castor Production from the Colonial Period to the Present Day}

Castor is a fast-growing herbaceous evergreen or semi-woody shrub. Its distinctive palmshaped leaves are either glossy green or purplish red on long leaf-stems (Sanders 1896). The plant is regularly propagated by seed, but has the ability to self-seed and can be invasive, establishing itself in less-cultivated 'wild' areas in the deep-south and reaching up to 3 metres in height in just one season. It can thrive in harsh nutrient-poor and dry conditions, and although it prefers more fertile and moister soils, if available, these are often lacking in the

\footnotetext{
${ }^{24}$ In 1769, prickly-pear cactus (Opuntia monacantha) was introduced to Madagascar for use as protective hedging (Kaufmann and Tsirahamba 2006). The Malagasy soon learnt to use this formidable defence against French armed forces patrolling throughout the south. The French were forced to introduce an exotic beetle, which decimated the cactus and provoked a famine in the 1930s. Later, colonial powers had to reintroduce cactus species as Malagasy dependence upon the plant had become too important for food, wind breaks and cattle fodder (Razafindrakoto 1977).
} 
poorer agricultural zones used for castor production in the south. In fact, the plant's ability to thrive in harsh climatic conditions was very attractive to the French during the colonial period and one of the main reasons they chose the southern region as its primary site for production. ${ }^{25}$

Castor beans are thought to have first arrived in southern Madagascar through various maritime trading routes with India. The first known local sub-species was $R$. communis var. minor, believed to have originally been cultivated in Hindustan, where it is often referred to as 'Bombay Small Seed' (although the species itself probably originated in north Africa). The dry sub-tropical conditions in Madagascar assisted the alien plant to establish (François 1934). The oil derived from the seed has historically been used by locals to condition hair and provide fuel in lamps. However, global demand for castor began to increase during the outbreak of World War I. At this time, major strides forward were being made in aeroplane engine design, many of which used castor oil as a lubricant in their crankshafts. Later, in the 1920s and 30s, blends of castor and mineral oil were very effective for car engines as well. Madagascar's castor beans were first recorded in French colonial export statistics from 1920 onwards. Prior to this date, castor production was assimilated into colonial export records for a diverse range of hand-collected 'oleaginous' seeds including baobab and native jatropha. In 1928, France's energy services, supplying lubricants to its Aviation, War and Maritime Department, encouraged national production of castor beans aligned to French colonial countries. At the launch in 1920, 720 tonnes were produced; this soon more than tripled to reach 2,500 tonnes by 1929 (François 1934), and as high as 3,300 tonnes in 1940 (Menet et al. 1982).

\footnotetext{
${ }^{25}$ Paradoxically this still provides an opportunity for private sector and development agencies seeking to maximize efficiency from the southern regions' 'underutilized' lands (Baka 2012).
} 
Castor oil for colonial needs was initially provided by local farmers collecting from relatively abundant plants growing semi-spontaneously near their villages. At first, the commissariat encouraged local farmers and intermediaries to take on the hard work of clearing land and establishing plots for castor. This was only the beginning of uneven trade in castor, as demand was anything but consistent. For example, a shortage of orders in 1933 provoked outrage and small skirmishes by growers looking to sell their full storehouses. Colonial authorities did not want the farmers to be dependent upon orders from the commissariat, but equally wanted to lower costs for their needs, in particular transport costs, which were viewed as excessive from isolated trading posts. The administration also recognized that excess production above their needs would necessitate absorption by the private sector and soon lower prices, rendering in vain the service's initial strategy to control production and collection of castor beans using premium pricing tactics.

The authorities sought to improve production in the region by removing ageing stock and weeding to stimulate younger plants. Despite this, parasitic losses from colonial harvests accounted for up to 40 per cent of entire production and reduced yields to less than $150 \mathrm{~kg} / \mathrm{ha}$. Meanwhile, crop damage was also often correlated with drier periods of the year, when there was less vegetative ground cover for pests, encouraging them to attack stands of castor plants (BDPA 1965). This risk of loss and eventual failure due to drought-prone conditions and pests has been a historical problem for many crops in the southern regions (Middleton 1999).

Post-colonial French agricultural support for the cultivation of castor foresaw, by 1970, castor fields reaching 7,000 ha and producing up to 5,000 tonnes of seed per annum with the potential for pressing facilities (BDPA 1965). Based on highest or projected historical records for castor seed production, this yield represents approximately 20-30,000 ha under traditional cultivation, producing 400 litres of castor oil per tonne of seed (Razafindrakoto 1977). Yet more technical advancement in mineral and synthetic oil blends led to superior lubrication 
specifications from modern oils leading to a decline in cultivated castor fields from the 1970s, as synthetics took precedence around the world (Menet et al. 1982). ${ }^{26}$

Production efficiency proposals also suggested siting of oil presses in proximity to farmers in the south to reduce production volumes by approximately 60 per cent, thereby lowering transport costs and being cheaper than pressing in France. Needs for crushing machines were discussed again during revived castor oil development operations in the 1960s (BDPA 1965); however, we have found evidence of at least one colonial factory with presses operating in Fort Dauphin in the early 1950s (see Figure 1). ${ }^{27}$

\section{Figure 1 about here}

Although castor accounts for only 0.15 per cent of world vegetable oil production, it has increased by over 50 per cent during the past 25 years (Patel et al. 2016). Today, worldwide production of castor oil was reported at approximately 600,000 tonnes/year, while seed remains high, reported in 2014 at 1.98 million t/y, down from its highest production totals of 2.5 tonnes in 2010 (FAOSTAT 2016) (see Figure 2). India dominates the global castor oil market with about 80 per cent of production (Pavaskar and Kshirsagar 2013). While Africa and the Americas come in a very distant second for global production, the market is growing (FAOSTAT 2016). One reason for this increased interest in castor and other biomass schemes has been the promotion of regional development through large-scale agricultural investment in the early 2000s to capitalize on a growing alternative energy market, and what is generally observed as 'underutilized' land and available labour (World Bank 2010). Because castor is

\footnotetext{
${ }^{26}$ Seeds of colonial-era castor in the arid south of Madagascar were collected during the dry seasons from July to October. Although the marginally moister conditions in the eastern sector of the Androy region provided better climatic conditions for the plant, the drier west dominated production mainly due to ease of establishment in more 'underproductive' and refused plots.

${ }^{27}$ This subject has been raised for decades, although no commercial presses for oil appear to have been sighted in the castor-producing areas until the recent establishment of castor collection and a processing plant in 2008 at Tsihombe.
} 
grown in rural semi-arid climates, annual production varies greatly mainly because of fluctuations in rainfall and the area devoted to planting. ${ }^{28}$

\section{Figures $2 \& 3$ about here}

Due to this surge in demand, peripheral areas in African countries such as Kenya, Mozambique and Madagascar quickly became 'hotspots' for biomass production (Carmody 2011; Neimark et al. 2016). While small in terms of overall biomass production, what makes today's castor production in Madagascar so relevant is that it provides a critical window into the effects of bringing a precarious labour force into the boom and bust cycles observed in both the global and Malagasy production history (see Figures 2 and 3, respectively). Once again we see the effects of the rhetorical and material construction of 'value chains' as a method of delivering economic development through the mobilization of a workforce and commoditization of frontier natures in attempts to somehow even out this regional development and reach those who are most marginal.

\section{CASTOR PRODUCTION AS AN ECOLOGICAL COMMODITY FRONTIER}

This vision of 'regional economic development' in the south remains alive today in part through the UNDP's poverty alleviation support programme in collaboration with the European Community and GIZ. Claudia Maier, the GIZ project leader in charge of their castor operations, was quoted in The Guardian discussing the importance of castor's historical trade on today's income generation schemes:

Madagascar was one of the biggest exporters [of castor] during the colonial era ... Castor oil plants can cope with drought and soils with a poor mineral content. The seeds are

\footnotetext{
${ }^{28}$ The spike in production in 2011 (which actually began in 2009) seemed to be caused by an increased demand from the European Union and China looking for a cheaper substitute to use in the manufacturing of industrial products and biofuels driving up prices and motivating farmers to increase yield to tap into an increased market share (Severino et al. 2012, 868).
} 
harvested in October and November, so it has the advantage of providing a source of income while waiting for other crops ... Seventy years ago Androy was famous for its castor oil (van Eeckhout 2015).

Yet, these contemporary development narratives surrounding income generation and food security cannot be taken out of their historical context; for many they are closely linked to years of historical encounters in the deep-south to source castor, and previous discourses to 'develop the south' through the colonial/post-colonial oil trade resonate closely with recent interventions to encourage production and participation in global value chains (Marley 2016; Mintz 1985; Moore 2000). Therefore this study exposes the complexity of seeing the bioeconomy as a 'new' market-based instrument and its not-so-neat alignment with the cycles or temporal patterns (origins, development and crisis/exhaustion) observed in other commodity frontier studies (Marley 2016). One can certainly say the 'bioeconomy' is a winwin' development trope for 'income generation' and a way to confront the global carbonconstrained economy - a pattern emerging throughout the global south as new bioeconomy frontiers are observed from Indonesia to Brazil. In reality, castor production is in many ways only a reinvention of previous interventions which seek to develop the south through the widening and deepening of market relations.

Financial and technical support for the construction of the firm's pressing factory in Tsihombe, provided by development agencies such as the European Community and GIZ, is a case in point (see Figure 4). This new factory was equipped with cold-pressing machines, filtering technology, drums and packaging materials, all purchased though subsidized development funds. ${ }^{29}$ This 'upgrading,' of processing capacity, designed under the valuechain umbrella, according to the firm's manager, is meant to deliver jobs and provide added-

\footnotetext{
${ }^{29}$ Note this does not fit the standard definitions of upgrading, nor is it the replacement of new versions of similar products, since the pressing factory did not exist before the company began in 2009. Currently, they produce approximately 100,000 litres of castor oil per year.
} 
value 'in country' through semi-processing of the castor oil in Madagascar rather than export as grains. ${ }^{30}$ The pressing factory only employs about 15 people, but development agencies argue that it extends the processing capacity and therefore added value can reach thousands of small-scale harvesters in an area with little else (see earlier Figure 2). This is noted in a laudatory description by the project funder of how the castor pressing factory will help '.. generate[s] higher incomes from increased production volume and better product quality' (GIZ 2014). Yet, as we see below, it also justifies extending and intensifying production as the increasing capacity of the pressing factory makes it feasible to widen the catchment area and increase wild collection of castor and the unpaid labour to transport it.

\section{Figure 4 about here}

Development agencies themselves are central to the structure which can deliver what they refer to as 'innovative (appropriate) technologies and value-chain upgrading', but are also involved in developing local land governance in the form of property rights and taxation, organizing collection associations and mobilizing local labour (Moore 2015, 158). The new organizational forms or what Araghi calls 'revolutions' fuse together 'territorial and capitalist organization with technical innovation' (Moore 2015, 160) which can help extend cycles of capitalist accumulation across time and space. This is not just a technical revolution, however, but a spatial and social expansion into deep-southern outgrowing regions which through years of economic and political marginalization are primed for continued accumulation. $^{31}$

\footnotetext{
${ }^{30}$ Interview with regional manager [7 July 2014].

${ }^{31}$ There were no women reported to be working at the pressing factory.
} 
Regions in the central massif and western savannahs of the island have observed large-scale agribusiness investments over the past 10 years (Andrianirina-Ratsialonana et al. 2011). ${ }^{32}$ Yet, beyond castor, the deep-south has been relatively quiet: this seemingly innovative project stands out. There were some bioeconomy-based start-up firms which were originally connected with larger agribusiness; however, many have since shut down in the south, mainly due to a drop in global demand and lack of production. Also, because of the difficult droughtprone conditions, risk of pests, and poor soils, most agribusinesses see investment into larger plantations in the south as too risky, opting for more risk-averse strategies, such as outgrower schemes, which need much less start-up capital.

There are a number of reasons why the firm chose to use outgrowers over plantations. ${ }^{33}$ First, according to the firm it is extremely expensive and time-consuming to acquire official land titles for plantations, particularly in the south. This was further explained to us by Giles, the head of a civil-society group who set up the original castor deal with the UNDP:

Some of the investors went alone to discuss with the mayor how to make a deal for 100 or 500 ha in their communes, while others contacted the chief of the region. So each investor has their own approach ... And the problem is that when the investor starts to exploit the land, they have [land] problems with the community. And it's a very big risk for their investment ... [The firm] may have a certificate for this space, but the community won't accept that they have rights there. And when the investor begins their activities, the community may try to fight against the firm...

The land is generally governed by a host of formal state claims overlapping with layers of unrecognized customary claims based on lineage (Raison-Jourde 1991); and as noted by

\footnotetext{
${ }^{32}$ For more on property rights and land deals in Madagascar see Neimark (2016).

${ }^{33}$ According to the firm operators, they are the only sizeable castor oil production system exporting off the island of Madagascar. As noted, they only use outgrowers.
} 
Giles, without secure and state-recognized land titles, investors run the risk of sabotage and organized resistance from rural inhabitants. Again, this is something firms are actively seeking to avoid in a 'post-land grabbing' environment.

Second, castor is found across an extensive area where regional road infrastructure is very poor; the outgrower labour force can both access the very remote areas and transport castor back. In order to access the castor, the firm needs to negotiate road taxes with local officials, providing freedom of movement in the region. As noted by Robert, the head of a development NGO which helped negotiate the deal: 'The head of the region saw that there would be this firm in the region, and this firm needed to use the road to transport the product. Yet, he must pay tax ... but this is negotiable, because the price of the road tax depends on many factors, and there is little justification on how much it should be ... so he made up a number.' Road taxes are set as part of the redevance, or return tax back to the regions. More generally, they are not 'separated out' and negotiated by individuals, but set at a fixed rate at the Ministerial level depending on the type of commodity. Yet, this 'tax break' negotiated on behalf of the firm is an example of the extent to which many of the barriers of market-based development are removed, sometimes to allow capital to reach the most marginal and inaccessible areas.

Third, by contracting smallholders to collect and grow castor, the firm circumvents the need to pay wages or provide any social benefits (health benefits or social security) usually demanded by plantation workers in Madagascar. This allows for limited capitalization as the firm only needs to invest in the most minimal of inputs (such as new varieties, seeds and storage sheds) in order to maintain its current collectors and entice new groups of growers. These alongside other 'hidden' costs, such as risks associated with the crop failure due to pests and disease which are a common occurrence with smallholders in Madagascar (Harvey et al. 2014) are now taken on by the household (Bernstein 1986). Friedmann (1990) and 
others (Moore 2015) argue that this is inherently 'patriarchal' since household reproduction costs are mainly covered by women.

On a related point, the use of outgrowers fits neatly into the value-chain scheme: the more collectors of the plant, the more target numbers, including women who are integrated into the project, as according to the NGO 'households managed by women were to be integrated into the relevant value chains' (GIZ 2014). In order to recruit labour, development agencies set up a ‘food-for-work' scheme called a 'High-Intensive Labour' public works programme (HIMO) ${ }^{34}$ Developed by the World Food Programme (WFP), Malagasy who participated in this scheme worked in selected projects and were paid either with food disbursements or cash. Workers in the HIMO cleared land for new test plots of castor throughout the region mainly because, according to Robert, '...that's what the development donors wanted to fund':

Robert: The analyses showed us that it is the donors who decide 'we will do this, we will finance this'. Government and the national authorities will say that we need your money to do this activity, but in the end it's always the donors who get to decide what to fund.

Interviewer: So it's the donor who is defining what the money is for?

Robert: Yes, and it's usually the regional or the national co-ordinators who are accepting without really much negotiation because in the south there is a lot of potential. The new port is not far, and there is a lot of land to exploit. It all depends on the donor and on who you work with.

This is just one of the many historical examples of regional development agencies mobilizing rural labour into castor schemes. Yet, the justification of recent labour mobilisation rests on the promises (and perils) of humanitarian work for food security and income generation. It

\footnotetext{
${ }^{34}$ Haute Intensité de Main d'Oeuvre or HIMO has, over the years, raised serious concern and contestation between humanitarian development agencies and local NGOs. Locals organizations claim that the WFP often accepts what it can get from its international supporters (e.g. foreign grain) even if that could destabilize local food production prices.
} 
Please note: This is a pre-edited copy.

wasn't very long ago that these HIMO programmes were re-packaged under the castor value chains. Placing humanitarian aid as an enticement for new investment schemes is an example of new organizational forms which assist in extending accumulation to include the southern region's most marginal workers. Castor production is therefore widened and extended through a bundle of agency networks and donor-funded projects and discourses of added benefits, value chains and upgrading. These 'upgrades', however, are mainly concentrated at the level of the firm; in contrast, new technology and skills 'halt at the farm gate', with costs (and risks) of production taken on by harvesters whose benefits, as we will see below, are meagre at best, yet whose risk remains high (Mann and Dickinson 1978).

\section{WIDENING COMMODITY RELATIONS: RECRUITMENT AND MOBILIZATION OF A} PRECARIOUS LABOUR FORCE

Castor is mainly found growing wild and in semi-managed small-scale plots over a large range of the southern regions of Anosy and Androy. This stretches from Ambosary in the east to the western towns of Marolinta, and from just north of Tsihombe to the southern coastal village of Faux Cap (see Figure 5). One reason for this wide range into semi-wild areas is because of the plant's ability to disperse its seeds and easily establish in the dry scrubland of some of the more marginal farming zones. Sometimes castor is kept in fallow rotations because locally it is believed that it can help deter some insects from eating other staple crops and keep soil from eroding in degraded areas. While whole families prepare the fields for planting, women usually harvest and dry seeds in September and October. After drying, castor beans are stored temporarily in 'drop-off' collection kiosks near or close to the main transport road until they can be picked up by the firm. Each collection kiosk can hold 5-10 tonnes of beans and harvesters will transport the seeds in gunny sacks on their backs (less than $10 \mathrm{~kg}$ ), in locally made wheelbarrows (less than $30 \mathrm{~kg}$ ), or using ox-drawn carts (over 30 $\mathrm{kg})$. 


\section{Put Figure 5 (map) here}

It is up to the firm to navigate the tricky logistics of bad roads and widely dispersed kiosks to pick up the castor seeds and bring them back to the pressing factory just outside the centrally located town of Tsihombe. The closest drop-off point to Tsihombe is roughly $25 \mathrm{~km}$, and the furthest, $110 \mathrm{~km}$. From the pressing factory, the commodity chain is fairly simple. The beans are pressed and the semi-processed oils transported in containers to the Ehoala Port in Fort Dauphin. ${ }^{35}$ The oil is then exported to European buyers who purchase it in bulk for the manufacturing of bioplastics, biofuels and the cosmetics industry. ${ }^{36}$

The castor seed is sown from March to May. An individual harvester's labour availability is a crucial factor in whether or not they will decide to take part in castor production. Although both men and women are encouraged to take part, female collectors are targeted as vital actors in the value chain due to their experience in growing and using castor as hair conditioner, but also for 'visibility' as development agencies often want to highlight their attention to improving gender equality. ${ }^{37}$ Many of the labour dynamics also play out along these distinct gender lines. Men have the ability to be away all day from the village and have access to different forms of transport, whereas many women do not have either the time or the access to transport to collect enough to make it worth their while. This is especially the case if women do not have a zebu cart and need to rent one, cutting into their profit margin. ${ }^{38}$ This was noted by a female harvester who had to collect and carry her own castor to market: 'We get paid in weight, so for example a standard gunny sack [women can carry half a full

\footnotetext{
${ }^{35}$ Funded as a joint venture by the Malagasy state and the mining giant Rio Tinto QMM, the port is estimated to cost roughly US \$275 million. See http://www.ehoalaport.com/ [accessed on 15 March 2016].

${ }^{36}$ Interview with regional manager [7 July 2014].

${ }^{37}$ Specific methods used by the firm to bring women into the 'value chain' were not elaborated on when asked about and little data exists in the project documents as to how women are targeted as benefit recipients of castor production.

${ }^{38}$ Zebu is the Malagasy name for locally known breeds of cattle.
} 
sack] filled with rice is not the same weight for the bio-oil seeds. We need to work a lot [as compared to rice], but it is not enough weight. It's not enough money in the end. Although we work a lot to get many seeds, it's still not enough because the yield doesn't have much weight.' Farmers' labour is embedded in the transport for which they are not compensated. For the firm, there is a distinct advantage to building drop-off points as it does not have to pay the extra cost of transport to get to the harvesters' villages to pick up the beans; instead the growers have to transport the seeds themselves. There are roughly 29 drop-off points along the main transport routes in the region, with plans to add another 25 points in 2014. Each drop-off point is fed by roughly $300-350$ collectors. On average, within a catchment area, collectors will travel a minimum of $3 \mathrm{~km}$ and sometimes up to $7 \mathrm{~km}$ to collect the seeds and bring them back to their village or to transport them directly to drop-off sites. However, individual harvesters do not get paid to transport castor as distance travelled is not reflected in the final price paid by the firm. Harvesters are therefore subsidizing the transport costs, causing many to question their participation, so vital for the firm's ability to mobilize a labour force. Without management restructuring allowing this labour to be recruited from within, the firm would be unable to keep a continual flow without the voluntary will of the harvesters to transport the crop. As Giles, the head of the NGO start-up project, notes:

Madagascar really needs these projects, this investment, to develop the country. But you have to have good management. For example, in each project you have to do some study ... to see what the reality is in the field, and how to adapt our actions or our activity with this reality ... I think that everyone, international level, national, local level, want investment in Madagascar. But, you have only to put in place a standard rule for each investor who wants to invest in Madagascar, because I think each investor needs land, needs a good relationship with the community, with authorities, with everyone. 
Here we can see the organizational forms of the commodity frontier develop and manifest. The firm's relationships with different actors along the castor commodity chain differs depending on its maintenance of an expanding network of local elites, many of whom are the head of the village (Fokontany), and act as collection managers or village leaders of 'new growers' associations'. The intermediaries organize the associations, which in turn help to organize harvesters in the village. Not everyone wants to participate in castor production or has the means to do so even if they did want to. It was noted by one intermediary that he had no interest in participating, and as for many others it brought back memories of the colonial production systems in which his recent ancestors had been involved. He called castor '... another vazaha [foreigner in Malagasy] crop.'39

The fact that this was not a 'home-grown' idea was a theme that came up quite often in our interviews, and some in the villages noted a particular schism between those who felt that they should keep to 'traditional' farming ways and those who embraced the new. Others noted that introducing foreign crops went along with other intrusions into their cultural customs, which they attached to foreign development. This was made clear by one of the association heads:

Traditions like the being discrete about cattle ownership, or to go to the ombiasy [traditional healer] to use plants to ward off diseases. It's our half of the village not in the association which keeps the tradition. We don't follow the vazaha traditions. The oil plants are not traditional ... it is a tradition of the vazaha. But many plant it now. It's the FAO that made us plant it for the food for work programme. For those of us who don't have work or food. They made us plant it. ${ }^{40}$

\footnotetext{
${ }^{39}$ Anon [4 July 2012]. In all of the village associations, we did not observe any headed by a woman.

${ }^{40}$ Anon [13 July 2014].
} 
While this initial resistance to participating in castor production could easily be seen as a sign of what we term casual traditionalism or perceived resistance to new methods of farming, a more critical view suggests that this is also a calculated position against getting 'tied up' once again in the risks of yet another vazaha crop. One villager, a small grower of castor, expressed their thoughts on perceptions of the project: ' ... this is not a bottom-up idea ... they gave us the idea, the "bio-oil people", they told us this proposal and we just did it as we were told it would work.' This sentiment expressed by a few informants is understandable given that many remember quite well the mixed history of imposed cropping boom and bust cycles tied to global commodity fluctuations, while other castor varieties not adapted to local environmental conditions eventually led to crop failure and losses due to pest damage (see below on commodity deepening), not to mention its colonial ties to the past (see Middleton 1999). ${ }^{41}$

Although not a feature in all villages, the associations which are meant to overcome these historical tensions also exacerbate inequalities, as association heads (often selected through social status and level of education) often get access to the benefits. They also play an important role in establishing work contracts as most of the information from the company is passed through them. It is through these associations that the firm communicates production quotas and delivery dates. While written contracts are rare, the head of the association usually formalizes agreements between local participants and the firm. These agreements are meant to be based on 'quantitative commitments' and help in locking in a base of growers who would be guaranteed a set price for their castor (Gibert 2014; Richer 2015). In return for their formal agreements and in attempts to lure more into joining, some harvesters are given

\footnotetext{
${ }^{41}$ A major ecological concern for the firm is moisture content and rot. Therefore there is a lot of training directed at the heads of the association in drying techniques and post-harvest handling so that the seeds can be properly spread out and turned correctly, shielding them against moisture build-up prior to transport.
} 
improved and new hybrid seed varieties, cash advances in the form of loans, and training courses and technical assistance on effective agricultural techniques (Gibert 2014).

It was reported to us that one of the regions included up to 30 associations, and there were three within one village alone, with some more on the horizon as recruitment strategies begin to take hold. One such strategy is the gifting of material incentives for top producers, who generally tend to be association heads. As one grower noted, 'the one who produces first gets a plough or wheelbarrow, those who get the highest yield, like when you get 500 or 600 kilos, you get that as a gift....' This method of 'gifting' is also a throwback to the colonial period, when top harvesters were given extra seeds and other benefits to increase production. Nonetheless, the firm's internal recruitment methods seem to be working, as recent firm estimates place up to 6,000 individual producers taking part.

The structure and make-up of the growers' associations are organized by the head of the village $^{42}$ : the way restructuring takes place is actually based on the earlier colonial commodity chains of castor and other outgrower schemes described above. A village leader sets up an association to organize and manage the labour force. In some villages the association governance has a secretary who holds and disperses the money, while in others they may invest in micro-projects around the village or in food or other cash crops; however, money is mainly filtered through the association and given directly to farmers with a little bit held back for administration costs.

The assignment of the association heads and the associations was noted by farmers as being based on already-established contacts, many of them with family members or close friends and kin-networks. Although many of the associations were still new at the time that we conducted the surveys, there was certainly a distinctive class of farmers emerging. Results

\footnotetext{
${ }^{42}$ Usually always a village male.
} 
also showed that adoption of castor was mostly found to be by 'better-off' extended family networks. For example, we found that 39 per cent of those growing castor had access to primary education. In contrast, only 23 per cent of non-harvesters had access to primary education. The adopters were also found to have fewer periods without food and a majority were primary owners of zebu as compared to those who did not adopt castor. ${ }^{43}$ Early indications show an uneven dynamic in which historic patron-client relations observed during colonial and post-colonial periods seem to be repeating themselves and where differential treatment may be afforded to those who are already better off. While it was difficult to see major class differentiation developing between harvesters, it does seem that wealthier and more-progressive farmers - many of whom have had experience working with the project and other NGO-sponsored projects in the past and have the finances and capacity to take on castor - will also to be the ones who are the early beneficiaries. Yet, if anything, as the project expands and intensifies, early indications do point to the potential to exacerbate structural gender inequalities that already exist.

By far the most important task of the head is to keep production flowing in the most out of reach areas and control the numbers of producers dropping out. In those which are not accessible by road, seeds and other materials are trucked-in. However, this is not the job of the firm alone as significant support is provided by local mayors. When asked where the seeds were coming from, one farmer responded, '...they get it from the mayor. There is a car coming bringing it here which arrives from the factory in Tsihombe.' Castor production is not a small operation and within the first few years of production, the firm, together with EU assistance, delivered over 12 tons of seed and invested over 22 million Ariary (US \$6,700). Bags of seed were marked and handed out to willing farmers who registered to participate in

\footnotetext{
${ }^{43}$ Primary ownership of zebu is a distinctive marker of family wealth in southern Madagascar, although exact numbers are difficult to ascertain as it is a particularly sensitive subject. It was explained to us that asking someone how many cattle they own is similar to asking a neighbour how much money they have in the bank.
} 
the first seed trials. ${ }^{44}$ Positive responses to this early production were expressed: ' $\ldots$ because when there is good production, we get good money. We know that it is positive for us.' This is a lifeline for some during periods of drought: 'As you know there is drought here, no rain. So that plant is something that can survive here. Because in general things don't grow here, as you know when there is no rain we starve. When there is a drought, they get money from the ricin. ${ }^{45}$ Again, this is based on experiments with plants harvested repeatedly from the same wild progenitors that were grown during the colonial periods.

For the donors, a key factor in supporting these associations was to organize the labour force, professionalizing them to a new rural landscape influenced by private sector opportunities (Neimark 2016). Feedback on harvest and collection could be transferred and in return the producers could pick up new growing techniques, varieties of seed and, most importantly, how payments would be distributed. As noted by Leon, who heads up an NGO which helped broker the castor deal for the firm agreements:

In one association... there is a leader. We don't have the money, or the means, to help everyone, every member. But we can give only, for example, $10 \mathrm{~kg}$ of seeds, for the association and it's the turn of the association to decide how to distribute ... sort of greases the wheels of production. This way it's very easy to organize and professionalize them and give technical support of the producer and the association.

In some villages associations can run up to 240 families. Yet rather than diversifying, it seems that some of these families are devoting their whole plots to castor as it is the only way of making the extra work worth it, as noted by a local grower: ‘...before I mixed ricin with other crops but now I have decided to grow only castor because it returns more' . Even with

\footnotetext{
${ }^{44}$ In these early years, roughly 100 tonnes of seed were purchased by the firm and given out to farmers. The firm got a return rate of 40 per cent in oil. In optimal conditions, castor can return up to 200 litres ha/year.

${ }^{45}$ Anon [4 July 2014].
} 
this, there remains increasing tension concerning the benefits the harvesters receive for their labour. The firm keeps the prices they pay to the harvesters low so as to offset their transport costs from the drop-off points; at the same time, these prices must be high enough to maintain harvesters' interest. The firm is under increasing pressure to increase both yields and numbers of farmers, so as to offset the low prices they pay and those dropping out.

\section{DEEPENING COMMODITY RELATIONS: PERCEPTIONS OF PAY AND EXTRA-}

\section{HUMAN LABOUR}

While the project promotes market access and income generation for some of the most precarious farmers in Madagascar, the irony is that rather than being liberated, many seem ambivalent to its benefits at best and others are distraught. The main point of contention is pay. Farmers expressed a willingness to travel longer distances and transport castor, but emphasized that the pay had to match the labour involved. Among all of the critiques surrounding the project, the price of castor was the most frequent issue raised, especially by women who felt that hauling the castor took too much time.

This complicates the harvesters' relationship with the firm. Many agree that having the opportunity for some added income is vital, particularly during the lean months. As noted by one female collector: 'the good part is that it brings some money at least - to buy a bit of food, medicine for children.' Prices per kilogram of castor are set by the firm mainly based on the price given to them at the port. Since castor is sold to much larger international buyers as semi-processed oil, the firm managers argue that it has very little control over the price it pays to the harvesters and is also therefore at the mercy of the 'whims of global commodity fluxes'.

Yet for many of the female collectors, this is where support for the project ends, as their time devoted to transport begins to take away responsibility from household responsibilities (e.g. 
taking care of children, working in household gardens and cooking). For example, we observed whole families harvesting castor (see Figure 6). Simultaneously, we observed some women carrying babies or tending to small children during the work while also trying their best to keep up the demand for castor which needed to be ready for the long transport to the drop-off points. Adopting feminist political ecology approach, Schroeder $(1999,74)$ found that women horticultural gardeners in The Gambia would schedule their work regimes around household domestic duties, sometimes doing daily 'double-visits', demonstrating how women 'highly calibrated their work regimes to simultaneously address the social and ecological constraints they faced on a daily basis' $(1999,76) .{ }^{46}$ Moore's concept of work/energy is instructive here as it helps us understand how women's socially necessary labour time is valued and thereby increasingly capitalized under the bioeconomy $(2016,15)$.

\section{Figure 6 about here}

Following Moore here, this commodity deepening or capitalization includes the shift from their subsistence livelihoods growing cassava and maize to intensive 'petty commodity production' and livelihood integration in global political economic networks (Bernstein 2010). This includes an increase in the use of new castor varieties and faming inputs, such as fertilisers, to keep up production quotas. For many, this dependency on single crop production has had the perverse effect of increasing their vulnerability to crop failure, mainly due to pests and cyclic drought and cyclone-induced flooding, which historically they were able to hedge when growing a more diversified array of crops. For instance, the 2012 cyclone which hit southern Madagascar caused flooding damage to irrigated rice fields. Afterwards, there was a widespread infestation of locusts further damaging whatever crops were left (FAO 2013). This string of hazards continues to weigh heavily on the minds of farmers who are already contending with having to travel further into the fields to gather enough 'wild'

\footnotetext{
${ }^{46}$ See Schroeder (1999) for an excellent example of extra labour that women took on in development-promoted horticulture gardens in The Gambia.
} 
castor and being pushed by the firm to intensify production to make it worthwhile. However, it may not be long before some will not have the choice; as more of their land is converted to castor they may reach a point where they are too entrenched in production to navigate a way out (Schroeder 1999; Watts 1994).

Yet, still at these early stages, we observed that even the most marginal growers will make rational wage calculations based on benefits and opportunity costs. As Arni, the head of one of the castor associations noted about risk and price calculations farmers make: 'They [the growers] are not happy about the price. The firm wants to get more villagers involved but with the price so low, it's hard to get. They don't want to do it. There is not enough money in it, they say. Those who are interested are those who get money out of it. For them, it's not the work keeping them away, it's the price.'

While some villages that are close to the drop-off points are pulling in 500 tons and surpassing their goals, many more are dropping out. This is a worrisome sign for the firm, resulting in it concentrating on expansion and intensification of the catchment areas to include wild castor. The 'wilder' the castor harvested the longer they generally need to transport it. Because of this, women harvesters usually had a more critical view of the firm than men. As one woman, Ambrosa, interjected during an interview with both her and her husband Nari:

Interviewer: Are you happy about the existence of this association here? I mean the firm here.

Nari: Yes, it's okay.

Interviewer: What are the positive things that make you say it is okay for you?

Nari: Because when there is good production, we get good money. We know that it is positive for us. 
Ambrossa: But we are not happy about the price!

Interviewer: Who fixes the price, the firm or the association?

Ambrossa: The firm. They fix it, and we can do nothing!

Another woman commented:

The price of the firm is too low. The price per kilo is $200 \mathrm{Ar}$ and they tried to increase it to 400 Ar. Overall, the production is good for the population because they increase their revenue. But the problem is the price as compared to how much work is involved. Some collectors spend all day on collection and transport. They will leave in the morning and not return till the evening 12 hours later. The whole family will go, including children.

It is generally understandable why pricing remains a contentious issue. Given the precariousness of the harvesters and particularly that of women who do not hold customary rights to land, one might say that the difference between 200 and $400 \mathrm{Ar}$ could mean the difference between making it through the 'leanest' periods of the year. For instance, out of 120 harvesters we conducted surveys with, 31 mentioned that in the past 5 years they had increasingly 'more frequent occurrences without any food at all'. This represents roughly 26 per cent of all the harvesters questioned. Out of 55 people surveyed who did not participate in castor, only 16 had 'periods without food', this representing 29 per cent of the non-growers group. This means that neither growers nor non-growers of castor could achieve food security, clearly showing that the firm is underperforming in its stated development goal of overcoming periods of food shortage.

However, overall 66 per cent of harvesters said that the firm had not significantly contributed to their income since castor harvesting began, whereas only 15 per cent said that it had. Almost twice as many of the respondents who said their income had 'got worse' since castor production began were women. Apart from the money they receive or still think may come 
their way due to the firm's presence, many people identified other benefits they would like to see; 89 per cent identified better road conditions and transport, while 36 per cent said that they would like to negotiate some improved access to clean water. Thirty-three per cent of growers mentioned that they now have access to improved health, but only 25 per cent said that the firm was actually sympathetic to their needs. In the end, very little if any of these development services are part of the social contract of the firm or the associated development project devised by the agencies involved.

\section{DISCUSSION AND CONCLUSION}

The aim of this paper is to expand the theoretical framing of commodity frontiers through empirical contours of the bioeconomy crop castor in the deep-south of Madagascar. The paper engages with the socio-ecological and material relations bound up in the value chain of castor and its promotion of economic development for some of the most precarious rural inhabitants in Madagascar. According to its proponents, the bioeconomy is a solution for addressing ecological, economic and societal challenges through a transition from traditional ‘dirty' carbon-heavy resource extraction towards sustainable knowledge-based innovations in biotechnology. Yet, discoveries have, up to this point, failed to meet many of these lofty goals, and as such, the industry must continually expand to new areas and intensify biomass production (Borras and Franco 2011; White et al. 2012).

Taking a cue from Hughes (2011) mentioned earlier, we recognize the framing of the bioeconomy as a commodity frontier as part of a political project. It builds on, and moves beyond, the concept of commodity frontiers which is mainly centred within world ecology/systems thinking, to use in conjunction with regional and feminist political ecology. For our work, it simultaneously 'demarcates and opens up' empirical understandings of socio-ecological representations of agrarian change and better identifies how bundles of 
human and extra-human nature are 'refracted through particular historical-geographical formations' (Moore 2015, 38). The bioeconomy constitutes a socio-ecological frontier in that it effectively opens up nature and labour through commodity widening and deepening (Campling 2012). However, we are careful not to see these frontiers as abstract geographical spaces; on the contrary, we look at the discursive constructions of small-scale bioeconomy value chains by development agencies and the private sector, and the consequences of this framing within regional and feminist political ecologies and/or the distinctiveness of locationbased geo-historical settings (Harcourt and Nelson 2015; Schroeder 1999). Here we demonstrate that it is actually the latent or 'veiled' dispossession observed over years of marginalization which helps provide the backdrop for continued accumulation (Kelly 2011). In doing so, our study of the castor value chain helps scholars critically reflect on larger trends in sourcing the global south for biomass for new natural products and mobilizing of labour, bound up in larger discursive imaginaries of climate change adaptation and mitigation, poverty reduction and food security.

For instance, the use of value chains as a model for economic development assists in the justification for funding and materials needed to recruit labour. For the firm charged with sourcing castor oil, local outgrower recruitment remains a high priority. The more rural inhabitants they can get within the value chain, the lower the prices paid to individuals can remain while still touting large participation numbers. The larger numbers of rural workers help the firm overcome the challenge of transporting over geographically dispersed wild and semi-managed plots spread out over vast and in some cases very inaccessible areas throughout Anosy and Androy. More generally, harvesters have very few options. As such, many will continue to harvest castor even as the price they receive remains low, committing to participation even if it means self-exploitation (Watts 1994). Small-scale growers will take on the extra labour of transporting the material, thereby subsidizing the firm and any other 
Please note: This is a pre-edited copy.

extra risks of production (pests, disease and crop failure due to drought). Here, not only does bioeconomy facilitate widening and deepening but also exacerbates gender-based livelihood 'narrowing and shallowing' as their options become more limited through project involvement. ${ }^{47}$

These ecological agrarian questions are very relevant for scholarship looking at how benefits along the value chain break down distinctly along gender lines. While women are targeted with producing castor, results show they have less labour availability and less access to transport to get the product to the drop-off points; very few have access to their own land or management responsibility for the household finances, and they only have a marginal role in leading the grower associations or capturing monetary benefits. If anything, significant gender-equity questions concerning the socio-economic and environmental benefits and burdens of the wider bioeconomy need continual attention as most analytic frameworks continue to read inequality only through a myopic lens on differentiation through class (Harcourt and Nelson 2015). And while there are already a host of critical voices emerging from activists and civil society, some of whom are calling for more community-led transitions, integrated bottom-up strategies and ethical 'socio-ecological transformations' (Temper and Del Bene 2016), others are looking for more 'radical futures' (including multiple ontological meanings), some of which may be better positioned to address gender (Collard et al. 2015). Hopefully this work can help open up new frameworks for analyzing how commodity frontier formation develops unevenly and lacks equality in specific places of intervention.

\footnotetext{
${ }^{47}$ We would like to thank an anonymous reviewer for these insightful terms and help in better framing these dynamics under a feminist lens.
} 
Moving forward, this study should help proponents of the bioeconomy, who may think that value chains of higher-return products derived from biomass in lower quantities (e.g. natural products), and their uncritical framing in development discourse, is of particular concern. Our contribution moreover is to provide a regional political ecological lens to already rich rigorous analytical and empirical work on commodity frontiers. We hope that future work will consider drawing on this research from an array of sub-fields in geography, development economics and other related disciplines.

\section{REFERENCES}

Akram-Lodhi, A.H. and C. Kay, 2010. 'Surveying the Agrarian Question (Part 2): Current Debates and Beyond'. The Journal of Peasant Studies, 37 (2): 255-84.

Alonso-Fradejas, A. 2012. Land control-grabbing in Guatemala: The political economy of contemporary agrarian change. Canadian Journal of Development Studies/Revue canadienne d'études du développement 33 (4): 509-528.

Andrianirina-Ratsialonana, R., Ramarojohn, L., Burnod, P. and A. Teyssier, 2011. After

Daewoo? Current Status and Perspective of Large-land Scale Acquisitions in Madagascar.

Observatoire du Foncier a Madagascar, Rome: CIRAD, ILC.

Araghi, F., 2009. 'Accumulation by Displacement: Global Enclosures, Food Crisis, and the Ecological Contradictions of Capitalism'. Review: Fernand Braudel Center, 34 (1): 113-46.

Bailis, R. and J. Baka, 2011. 'Constructing Sustainable Biofuels: Governance of the Emerging Biofuel Economy'. Annals of the Association of American Geographers, 101 (4): 827-38.

Baka, J.E., 2012. Biofuels and Marginal Lands: An Interdisciplinary Examination of Jatropha Biodiesel Promotion in Tamil Nadu, India. New Haven, CT: Yale University Press. 
Please note: This is a pre-edited copy.

BDPA, 1965. Culture du Ricin dans le Sud de Madagascar et Perspectives de Développement. Antananarivo.

Bernstein, H., 2010. Class Dynamics of Agrarian Change (Vol. 1). Bloomfield, CT: Kumarian Press.

Birch, K. and D. Tyfield, 2013. 'Theorizing the Bioeconomy Biovalue, Biocapital, Bioeconomics or... What?'. Science, Technology \& Human Values, 38 (3): 299-327.

Birch, K., Levidow, L. and T. Papaioannou, 2010. ‘Sustainable Capital? The Neoliberalization of Nature and Knowledge in the European "Knowledge-based Bioeconomy”. Sustainability, 2 (9): 2898-2918.

Blaikie, P., 1985. The Political Economy of Soil Erosion in Developing Countries. New York: John Wiley.

Borras, S. Jr. and J.C. Franco, 2011. 'Global Land Grabbing and Trajectories of Agrarian Change: A Preliminary Analysis'. Journal of Agrarian Change, 12 (1): 34-59.

Borras, S.M., Franco, J.C., Gómez, S., Kay, C. and M. Spoor, 2012. 'Land Grabbing in Latin America and the Caribbean'. The Journal of Peasant Studies, 39 (3-4): 845-72.

Borras, S.M., McMichael, P. and I. Scoones, 2010. 'The Politics of Biofuels, Land and Agrarian Change: Editors' Introduction.' The Journal of Peasant Studies, 37 (4): 575-92.

Borras, S.M., J. C. Franco, S.R. Isakson, L. Levidow, and P. Vervest, 2016. The rise of flex crops and commodities: implications for research Journal of Peasant Studies 43(1): 93-115. Bosch, R., van de Pol, M. and J. Philp, 2015. 'Policy: Define Biomass Sustainability'. Nature 523: 526-27.

Broch-Due, V. and R.A. Schroeder, 2000. Producing Nature and Poverty in Africa. Nordic Africa Institute. 
Please note: This is a pre-edited copy.

Burnod P., Rakotomalala, H., Rasolofo, P., and A. Brès, 2015. Large-scale plantation and contract farming effects: qualitative and quantitative assessment in Madagascar Utrecht: LANDac, pp. 1-30.

Campling, L., 2012. 'The Tuna 'Commodity Frontier': Business Strategies and Environment in the Industrial Tuna Fisheries of the Western Indian Ocean'. Journal of Agrarian Change, $21(2-3): 252-78$.

Carmody, P., 2011. The New Scramble for Africa. Polity Press: Cambridge, UK, and Maiden, MA.

Castree, N., 2004. 'Differential Geographies: Place, Indigenous Rights and "Local” Resources'. Political Geography, 23 (2): 133-67.

Castellanos-Navarrete, A. and K. Jansen, 2015. Oil palm expansion without enclosure: smallholders and environmental narratives. Journal of Peasant Studies 42 (3-4): 791-816. Collard, R., Dempsey, J. and J. Sundberg, 2015. 'A Manifesto for Abundant Futures'. Annals of the Association of American Geographers, 105 (2): 322-30.

Cotula, L., Vermeulen, S., Leonard, R. and J. Keeley, 2009. Land Grab or Development Opportunity? Agricultural Investments and International Land Deals in Africa. London: IIED.

De Janvry, A., 1981. The Agrarian Question and Reformism in Latin America. Baltimore, MD: Johns Hopkins University Press.

Droy, I., Bidou, J-E., and P. Rasolofo, 2010. Pauvreté et sécurisation foncière : les atouts et incertitudes d'une gestion décentralisée à Madagascar. Revue scientifique internationale des civilisations Taloha, Antananarivo: ICMAA.

Fairbairn, M., 2015. 'Foreignization, Financialization and Land Grab Regulation'. Journal of Agrarian Change, 15 (4): 581-91. 
Please note: This is a pre-edited copy.

Fairhead, J., Fraser, J. and M. Leach, 2012. 'Green Grabs and Biochar: Revaluing African

Soils and Farming in the New Carbon Economy'. The Journal of Peasant Studies, 39 (2):

$285-307$.

FAO, 2013. Madagascar Locust Crisis - Response to the Locust Plague: Three-Year

Programme 2013/2016. http://www.fao.org/emergencies/resources/documents/resources-

detail/en/c/172406/ [accessed on 11 February 2017]

FAOSTAT, 2016. World Statistical Database. http://www.fao.org/statistics/en/ [accessed on

9 September 2016].

FAO, 2016. Crop Losses in Southern Madagascar Mean Severe Hunger Likely to Persist into 2017. http://www.fao.org/news/story/en/item/449030/icode/ [accessed on 11 February 2017].

Foster, J.B. and B. Clark, 2009. 'The Paradox of Wealth: Capitalism and Ecological Destruction'. Monthly Review, 61 (6): 1.

François, E. 1934. 'La Production du Ricin à Madagascar'. Revue International de Botanique Appliquee et d'Agriculture Tropicale.159: 930-38.

Friedmann, H. 1980. 'Household Production and the National Economy: Concepts for the Analysis of Agrarian Formations. Journal of Peasant Studies 7(2): 158-184,

Friedmann, H., 1990. 'Family Wheat Farms and Third World Diets: A Paradoxical Relationship between Unwaged and Waged Labor. Work without Wages: Comparative Studies of Domestic Labor and Self-Employment, eds. Collins, J.L. and M. Giminez, 193214. State University of New York Press.

Garvey, B., Tyfield, D. and L.F. Mello, 2015. 'Meet the New Boss... Same as the Old Boss? Technology, Toil and Tension in the Agrofuel Frontier'. New Technology, Work and Employment, 30 (2): 79-94. 
Please note: This is a pre-edited copy.

Gerber, J.F., and S. Veuthey. 2010. Plantations, resistance and the greening of the agrarian question in coastal Ecuador. Journal of Agrarian Change 10(4): 455-481.

Gibbon, P. and S. Ponte, 2005. Trading Down: Africa, Value Chains, and the Global Economy. Philadelphia, PA: Temple University Press.

Gibert, D., 2014. Rencontres avec des Entrepreneurs Africains: Comment Implanter une Entreprise dans une Région Enclavée et Traditionnellement Fermée?

http://www.diateino.com/blog/2014/10/24/7726/ [accessed on 13 February 2014]

GIZ, 2014. Improving Resilience by Developing Value Chains

https://www.giz.de/en/worldwide/29293.html [accessed on 3 February 2016]

Gontard, 1969. Madagascar Pendant la Première Guerre Mondiale. Société Malgache D'édition.

Goodman, D. and M. Redclift, 1991. Refashioning Nature: Food, Ecology and Culture, London: Routledge.

Goodman, D., Sorj, B. and J. Wilkinson, 1987. From Farming to Biotechnology. Oxford: Blackwell.

Guereña, A., and R. Zepeda, 2013._The Power of Oil Palm. Land grabbing and impacts associated with the expansion of oil palm crops in Guatemala: The case of the Palmas del. Ixcán company. Boston, Oxfam.

Harcourt, W., and I. L. Nelson, eds., 2015. Practising Feminist Political Ecologies: Moving Beyond the 'Green Economy'. Zed Books.

Heurtebize, G., 1986. Histoire des Afomarolahy (Clan Tandroy-Extrême-Sud de Madagascar). Doctoral dissertation, Paris: CNRS.

Hughes, D.M., 2011. From Enslavement to Environmentalism: Politics on a Southern African Frontier. Seattle, WA: University of Washington Press. 
Please note: This is a pre-edited copy.

Hunsberger, C. and A. Alonso-Fradejas, 2016. The discursive flexibility of 'flex crops': comparing oil palm and jatropha. Journal of Peasant Studies 43(1): 225-250.

Jarosz, L., 1996. 'Defining Deforestation in Madagascar'. In Liberation Ecologies.

Environment, Development, Social Movements, eds. Peet, R. and M. Watts, 148-64. Oxford: Routledge.

Kaufmann, J.C. and S. Tsirahamba, 2006. 'Forests and Thorns: Conditions of Change Affecting Mahafale Pastoralists in Southwestern Madagascar'. Conservation and Society, 231-61.

Kautsky, K., 1988. The Agrarian Question (Vol. 2). London: Unwin Hyman.

Kelly, A.B., 2011. 'Conservation Practice as Primitive Accumulation'. Journal of Peasant Studies 38 (4): 683-701.

Levidow, L., 2011. Agricultural Innovation: Sustaining What Agriculture? For What European Bio-Economy. Co-operative Research on Environmental Problems in Europe (CREPE). Milton Keynes: Open University. Available from: http://dpp.open.ac.uk Li, T.M., 2011. 'Centering Labor in the Land Grab Debate'. Journal of Peasant Studies 38 (2): 281-98.

Mann, S.A. and J.M. Dickinson, 1978. 'Obstacles to the Development of a Capitalist Agriculture'. The Journal of Peasant Studies, 5 (4): 466-81.

Marley, B.J., 2016. 'The Coal Crisis in Appalachia: Agrarian Transformation, Commodity Frontiers and the Geographies of Capital'. Journal of Agrarian Change 16 (2): 225-54.

Marx, K. and F. Engels, 1970. The German Ideology (Vol. 1). New York, NY: International Publishers Co. 
Please note: This is a pre-edited copy.

McKinnon, I. and C.C. Hiner, 2016. 'Does the Region Still Have Relevance? (Re)considering “regional” Political Ecology'. Journal of Political Ecology 23: 115-22.

McMichael, P., 2009. 'A Food Regime Genealogy’. The Journal of Peasant Studies, 36 (1): $139-69$.

McMichael, P., 2012. 'The Land Grab and Corporate Food Regime Restructuring'. The Journal of Peasant Studies, 39 (3-4): 681-701.

McMichael, P., 2013. 'Value-Chain Agriculture and Debt Relations: Contradictory Outcomes'. Third World Quarterly, 34 (4): 671-90.

Menet, L., Ravelojaona, G., Geneste, P. and A.M. Gaydou, 1982. 'Energy Resources of Plant Origin in Madagascar: Ethyl Alcohol and Seed Oils'. Oleagineux, 37 (3): 135-41.

Middleton, K., 1999. 'Who Killed "Malagasy Cactus”? Science, Environment and Colonialism in Southern Madagascar (1924-1930)'. Journal of Southern African Studies, 25 (2): 215-48.

Mintz, S.W., 1985. Sweetness and power. New York: Viking.

Moore, J.W., 2000. 'Environmental Crises and the Metabolic Rift in World-Historical Perspective'. Organization \& Environment, 13 (2): 123-57.

Moore, J.W., 2010. 'Amsterdam is Standing on Norway. Part II: The Global North Atlantic in the Ecological Revolution of the Long Seventeenth Century'. Journal of Agrarian Change, 10 (2): 188-227.

Moore, J.W., 2015. 'Ecology, Capital, and the Nature of Our Times: Accumulation \& Crisis in the Capitalist World-Ecology'. Journal of World-Systems Research, 17 (1): 107-46.

Neimark, B., 2010. 'Subverting Regulatory Protection of "Natural Commodities": the Prunus Africana in Madagascar'. Development and Change, 41 (5): 929-54. 
Neimark, B. Mahanty, S. and W. Dressler, 2016. 'Mapping Value in a "Green” Commodity Frontier: Revisiting Commodity Chain Analysis'. Development and Change, 47: 240-65.

Neimark, B, 2016. Biofuel imaginaries: The emerging politics surrounding 'inclusive' private sector development in Madagascar, Journal of Rural Studies. 45:146-156.

Neumann, R., 2014. Making political ecology. Routledge.

O’Connor, J.R., ed., 1998. Natural Causes: Essays in Ecological Marxism. New York, NY: Guilford Press.

Oya, C., 2012. 'Contract Farming in Sub-Saharan Africa: A Survey of Approaches, Debates and Issues'. Journal of Agrarian Change 12 (1): 1-33.

Pavaskar, M. and A. Kshirsagar, 2013. 'Global Castor Oil and Indian Monopoly'. Financial Vis 1: 15-19.

Patel, V.R., et al., 2016. 'Castor Oil: Properties, Uses, and Optimization of Processing Parameters in Commercial Production'. Lipid Insights 9: 1-12.

Peet, R. and M. Watts. 2002. 'Liberation Ecology: Development, Sustainability, and Environment in an Age of Market Triumphalism'. In: Liberation Ecologies: Environment, Development and Social Movements, eds. Peet R. and M. Watts. Routledge: London. Pp. 145.

Polanyi, K. [1944] 2001. The Great Transformation: The Political and Economic Origins of Our Time, 2nd ed. Boston, Beacon Press.

Ponte, S. and K. Birch, 2014. 'The Imaginaries and Governance of 'Biofueled Futures'. Environment and Planning A, 46 (2): 271-79.

Raison-Jourde, F., 1991. Bible et Pouvoir à Madagascar au XIXe Siècle: Invention d'une Identité Chrétienne et Construction de l'Etat, 1780-1880. Paris: Karthala Editions. 
Please note: This is a pre-edited copy.

Razafindrakoto, P. 1977. Contribution à L'étude du Ricin de L'extrême Sud Malgache. Antananarivo.

Ribot, J.C., 1998. ‘Theorizing Access: Forest Profits Along Senegal's Charcoal Commodity Chain'. Development and Change, 29 (2): 307-41.

Richer, J., 2015. Le Ricin, Solution Contre la Pauvreté à Madagascar?

https://medium.com/le-troisi [accessed on 14 March 2016]

Rocheleau, D.E., Thomas-Slayter, B. and E. Wangari, eds, 1997. Feminist Political Ecology:

Global Perspectives and Local Experience. Routledge.

Saguin, K., 2015. 'Blue Revolution in a Commodity Frontier: Ecologies of Aquaculture and Agrarian Change in Laguna Lake, Philippines'. Journal of Agrarian Change. doi:

10.1111/joac. 12114

Sanders, T.W., 1896. The Encyclopaedia of Gardening. 2nd edn. London: W.H. \& L.

Collingridge.

Schroeder, R.A., 1999. Shady Practices: Agroforestry and Gender Politics in the Gambia. Berkeley, CA: University of California Press.

Severino, L.S., et al., 2012. 'A Review on the Challenges for Increased Production of Castor'. Agronomy Journal 104 (4): 853-80.

Sodikoff, G.M., 2012. Forest and Labor in Madagascar: From Colonial Concession to Global Biosphere. Bloomington, IN: Indiana University Press.

Temper L., and D. Del Bene, 2016. 'Transforming Knowledge Creation for Environmental and Epistemic Justice'. Current Opinion in Environmental Sustainability 20: 41-9.

Tsing, A.L., 2000. Inside the economy of appearances. Public Cult. 12, 115-144. 
Please note: This is a pre-edited copy.

van Eeckhout, L., 2015. Castor Oil Helps Fight Against Poverty in Madagascar. http://www.theguardian.com/world/2015/feb/06/madagascar-food-security-castor-oil [accessed on 14 March 2016]

Vermeulen, S. and L. Cotula, 2010. 'Over the Heads of Local People: Consultation, Consent, and Recompense in Large-Scale Land Deals for Biofuels Projects in Africa'. The Journal of Peasant Studies, 37 (4): 899-916.

Walker, P.A., 2003. 'Reconsidering "Regional” Political Ecologies: Toward a Political Ecology of the Rural American West'. Progress in Human Geography, 27 (1): 7-24.

Watts, M.J., 1994. Life Under Contract: Contract Farming, Agrarian Restructuring, and Flexible Accumulation. In Little, P.D. and M.J. Watts, eds. Living Under Contract: Contract Farming and Agrarian Transformation in Sub-Saharan Africa, 21-77. Madison, WI: University of Wisconsin Press.

White, B. and A. Dasgupta, 2010. 'Agrofuels Capitalism: A View from Political Economy'. The Journal of Peasant Studies, 37 (4): 593-607.

White, B., Borras Jr, S.M., Hall, R., Scoones, I. and W. Wolford. 2012. 'The New Enclosures: Critical Perspectives on Corporate Land Deals'. The Journal of Peasant Studies, 39 (3-4): 619-47.

World Bank, 2010. Rising Global Interest in Farmland: Can it Yield Equitable and Sustainable Benefits? World Bank, Washington. 